\title{
Water-soluble chitosan from shrimp and mussel shells as corrosion inhibitor on tinplate in $2 \% \mathrm{NaCl}$
}

\author{
Harmami Harmami, Ita Ulfin, Arina Hidayatus Sakinah, and Yatim Lailun Ni'mah* \\ Department of Chemistry, Faculty of Sciences, Institut Teknologi Sepuluh Nopember (ITS), Kampus ITS Sukolilo, Surabaya 60111, Indonesia
}

* Corresponding author: yatimnikmah@gmail.com

\section{Article history}

Received 10 January 2018

Revised 4 September 2018

Accepted 11 October 2018

Published Online 14 April 2019

\section{Graphical abstract}

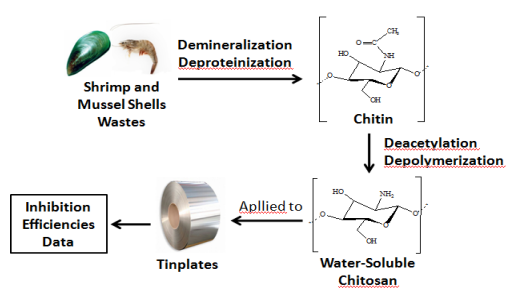

\begin{abstract}
Water-Soluble Chitosan (WSC) was synthesized from shrimp and mussel shells and used as corrosion inhibitor on tinplate in $\mathrm{NaCl} 2 \%$. Chitin was extracted from shrimp and mussel shells by demineralization and deproteinization reactions.Chitin was deacetylated to obtain crude chitosan. WSC was obtained by depolymerization reaction of the crude chitosan using $\mathrm{H}_{2} \mathrm{O}_{2}$. WSC performance as corrosion inhibitor on tinplate in $\mathrm{NaCl} 2 \%$ was studied by weight loss and potentiodynamic polarization methods. WSC inhibition efficiency was studied in various concentrations in the range of $10-1500 \mathrm{mg} / \mathrm{L}$. Maximum inhibition efficiencies of WSC from shrimp shells waste were $72.73 \%$ (weight loss method) and $91.41 \%$ (potentiodynamic polarization method), while maximum inhibition efficiency of WSC from mussel shells waste was $54.55 \%$ (weight loss method) with the addition of $1300 \mathrm{mg} / \mathrm{L}$ WSC concentration. Weight loss studies revealed that WSC acted as mixed type of inhibitor and obeyed Freundlich adsorption isoterm.
\end{abstract}

Keywords : Tinplate, corrosion inhibitor, water-soluble chitosan, weight loss, potentiodynamic polarization

() 2019 Penerbit UTM Press. All rights reserved

\section{INTRODUCTION}

Tinplate is low carbon steel coated on both sides with commercially pure tin. Tinplates are used in more than $80 \%$ of canning industry compared to the new alternative materials such as aluminium and chromated steel (Xia et al., 2012). The tendency of tinplate to become thinner upon application can trigger the increment of corrosion probability (Huang et al., 2014). On the other hand, the presence of $\mathrm{Cl}^{-}$ions in seafood and cured food products can damage $\mathrm{FeSn}_{2}$ layer on tinplate surface, which can also increase the corrosion probability (Xia et al., 2012).

Corrosion is a metal destruction process which caused by the metal stability that has a tendency to its oxidation state than to reduction state. It happens because of the interaction between metal and environtment (Trethwey \& Chamberlain, 1991). Tinplate corrosion can damage the appearance of the product and affect the nutritional value and healthiness of the canned food (Catala et al., 1998). Corrosion can cause high economic losses. According to study carried out by NACE (National Association of Corrosion Engineers) in 2011, total cost of corrosion in U.S was US \$2,2 trillion (Verma et al., 2017). Among some corrosion prevention methods, corrosion inhibitor has several advantages such as economically-wise, efficient and found in arious applications (Hamdani et al., 2015).

Corrosion inhibitor is a compound which can be adsorbed on tinplate surface, occupied the active sites and decreased the corrosion rate. Some studies are reported to find an alternative for inorganic inhibitor because of its function as an oxidator at high concentration. Therefore, a green organic inhibitor is needed. Many non-toxic organic compounds such as amines, phosphonate acids, heterocyclic compounds and carboxylic acids are reported as corrosion inhibitors (Aghzzaf et al., 2012). Biopolymer can be used as a corrosion inhibitor because it occupies on metal surface effectively and has high chelate ability, big molecular size and multiple adsorption sites. One of biopolymers which can be used as corrosion inhibitor is chitosan and its derivatives (Sangeetha et al., 2016).

Chitosan is a N-deacetylated product of chitin. Chitosan has a low toxicity, biodegradable characteristic and good adsorption ability (ElHaddad, 2013). Chitin and chitosan can be utilized in numerous industries including medicals, cosmetics, biotechnologies and food industries (Ghorbel-Bellaaj et al., 2013). Chitosan can be syntesized from chitin. Chitin can be extracted from crab, mussel and shrimp shells wastes (Arancibia et al., 2014). Chitosan can be used as corrosion inhibitor because of its high numbers of primary amine group which can bind on metal surface (Aghzzaf et al., 2012). Some researches on chitosan and its derivatives are reported that it can be used as corrosion inhibitor on many kinds of metal such as chitosan on tinplate in $3 \% \mathrm{NaCl}$ solution (Firdausi \& Harmami, 2014), chitosan on $\mathrm{SS} 304$ in 3\% $\mathrm{NaCl}$ solution (Wardani \& Harmami, 2014), chitosan on SS 304 in 3\% NaCl solution (Riszki \& Harmami, 2015), chitosan-doped-hybrid/TiO 2 nanocomposite on alumunium $3.5 \% \mathrm{NaCl}$ solution (Balaji \& Sethuraman, 2017) and water-soluble chitosan on mild steel in $1 \mathrm{M} \mathrm{HCl}$ (Saleh et al., 2017). From the previous study, it was found that chitosan and its derivatives were insoluble in $\mathrm{NaCl}$ media $(\mathrm{pH}>6)$ because of high molecular weight. This solubility problem makes chitosan has limiting application in aquous solution application. In this research, water-soluble chitosan (WSC) from shrimp and mussel shells wastes would be syntesized as corrosion inhibitor on tinplate in $2 \% \mathrm{NaCl}$. WSC performances as corrosion inhibitor were evaluated by weight loss and potentiodynamic polarization methods. Isothermal adsorption and thermodynamic studies were studied to find the WSC corrosion inhibition mechanism on tinplate in $2 \% \mathrm{NaCl}$. 


\section{EXPERIMENTAL}

\section{Materials}

The starting materials (shrimp shells waste) was collected from a local traditional market in Surabaya while mussel shells waste were pulverized in a mill and screened through a 40-mesh sieve. White tinplate (thickness $=0.1 \mathrm{~cm}$, density $=7.625 \mathrm{~g} / \mathrm{cm}^{3}$ and equivalent weight $=59.35 \mathrm{~g} / \mathrm{mol}$ ) was-in this study. White tinplate has tin layer with thickness of 30-50 $\mu \mathrm{m}$ in each side of carbon steel and the carbon steel itself has thickness of $0.094-0.09 \mathrm{~cm}$.

\section{Reagents}

$\mathrm{NaOH}$ pellets (Merck, 99.99\%), $\mathrm{NaOH}$ (SAP chemicals), $\mathrm{HCl}$ (SAP chemicals, 37\%), aqua demineralization, acetone (Merck, 99.99\%), ethanol (SAP chemicals, 96\%), $\mathrm{H}_{2} \mathrm{O}_{2}$ (SAP chemicals, $30 \%$ ), acetic acid (SAP chemicals, 30\%), absolute ethanol (Merck, 99.99\%) and $\mathrm{NaCl}$ p.a (Merck, 99.99\%) were used in this study.

\section{Solutions preparation}

Required $1000 \mathrm{~mL}$ of $10 \% \mathrm{NaOH}$ solution was made by dissolving $111 \mathrm{~g}$ of $\mathrm{NaOH}$ (SAP chemicals: density of $1.11 \mathrm{~g} / \mathrm{mL}$ ) with aqua demineralization in a $1000 \mathrm{~mL}$ volumetric flask. $100 \mathrm{~mL}$ of $50 \% \mathrm{NaOH}(\mathrm{w} / \mathrm{w})$ solution with density of $1.53 \mathrm{~g} / \mathrm{mL}$ was made by dissolving $76.5 \mathrm{~g}$ of $\mathrm{NaOH}$ pellets (Merck, 99.99\%) with aqua demineralization in a $100 \mathrm{~mL}$ volumetric flask. $100 \mathrm{~mL}$ of $2 \%$ $\mathrm{CH}_{3} \mathrm{COOH}$ solution was made by diluting $6.67 \mathrm{~mL}$ of $\mathrm{CH}_{3} \mathrm{COOH}$ (SAP chemicals, $30 \%$ ) solution with aqua demineralization in a 100 $\mathrm{mL}$ volumetric flask. Required $1000 \mathrm{~mL}$ of $2 \% \mathrm{NaCl}$ solution was made by dissolving $20 \mathrm{~g} \mathrm{NaCl} \mathrm{p.a} \mathrm{(Merck,} \mathrm{99.99 \% )} \mathrm{with} \mathrm{aqua}$ demineralization in a $1000 \mathrm{~mL}$ volumetric flask.

\section{Synthesis of water-soluble chitosan}

Synthesis of water-soluble chitosan was carried out according to proposed method by Du et al. (2009). Shrimp and mussel shells powder of $50 \mathrm{~g}$ was soaked in $500 \mathrm{~mL}$ of $\mathrm{HCl} 7 \%$ and then filtered. The residue of shrimp and mussel powder was soaked in $500 \mathrm{~mL}$ of $\mathrm{NaOH} 10 \%$ and then filtered. The soaking process of the powder in $\mathrm{HCl} 7 \%$ and $\mathrm{NaOH} 10 \%$ was repeated 3 times. The residue (chitin) of shrimp and mussel powder was washed with $125 \mathrm{~mL}$ of ethanol $96 \%$ and then was dried. The crude chitosan from shrimp and mussel powder was obtained from $10 \mathrm{~g}$ of chitin by soaking it in $20 \mathrm{~mL}$ of $\mathrm{NaOH} 50 \%$ before being filtered and washed with hot aqua demineralization, and then was dried. Crude chitosan (from shrimp and mussel shells) of $1 \mathrm{~g}$ was soaked in $10 \mathrm{~mL}$ of acetic acid $2 \%$ and 4 $\mathrm{mL}$ of $\mathrm{H}_{2} \mathrm{O}_{2} 30 \%$. The mixture was left to react using magnetic stirrer hotplate before being filtered in order to obtain the filtrate. Absolute ethanol was added into filtrate gradually and then incubated. The filtrate (from shrimp and mussel shells) was dried to obtain watersoluble chitosan. The percentages of chitin and water-soluble chitosan were calculated using Eq. (1).

$$
\% \text { Percentages }=\frac{\text { weight of chitin } / \text { WSC }}{\text { weight of sample }} \times 100 \%
$$

The chitin and water-soluble chitosan were characterized by Fouriertransform infrared (FTIR) spectrophotometer (Shimadzu FTIR$8400 S$ ). Deacetylation Degree (\%DD) of WSC was measured by titrimetric method (Czechowska-Biskup et al., 2012).

\section{WSC inhibition analysis based on weight loss method}

Tinplate surface $(2 \mathrm{~cm} \times 2 \mathrm{~cm} \times 0.1 \mathrm{~cm})$ was washed with water, followed by acetone. After that, tinplate was dried for 20 minutes at $60^{\circ} \mathrm{C}$ and then placed for 30 minutes at room temperature. The initial weight of tinplate (W') was measured. The corrosion media used in this research was $\mathrm{NaCl} 2 \%$ with and without WSC (from shrimp and mussel shells) at various concentrations $(0,10,250,200,750,1000$, 1300 and $1500 \mathrm{mg} / \mathrm{L})$. Tinplate $2 \times 2 \mathrm{~cm}^{2}$ was soaked in $15 \mathrm{~mL}$ of corrosion media for 72 hours, then lifted and washed with water and acetone. The tinplate was dried for 20 minutes at $60^{\circ} \mathrm{C}$ and then placed for 30 minutes at room temperature. The final weight of tinplate (W) was measured. Corrosion rates (mmpy), surface coverages $(\theta)$ and inhibition efficiencies (\%) of WSC were obtained from the initial and final weights of tinplate. The corrosion rates (CR), surface coverages $(\theta)$ and inhibition efficiencies (IE) were calculated using Eq. (2), (3) and (4), respectively.

$$
\begin{aligned}
& C R(\text { mmpy })=\frac{0.000875 \times\left(W-W^{\prime}\right)}{\rho \times A \times t} \\
& \theta=\frac{\Delta W-\Delta W_{i n h}}{\Delta W} \\
& I E(\%)=\theta \times 100 \%
\end{aligned}
$$

$\mathrm{W}$ is weight of tinplate before being immersed in corrosion media ( $\mathrm{g}$ ), $\mathrm{W}^{\prime}$ is weight of tinplate after being immersed in corrosion media (g), $\rho$ is density of tinplate $\left(\mathrm{g} / \mathrm{cm}^{3}\right)$, " $\mathrm{A}$ " is the surface area of tinplate $\left(\mathrm{cm}^{2}\right), \mathrm{t}$ is the immersion time of tinplate in corrosion media, $\Delta \mathrm{W}$ is weight differences of tinplate without the addition of water-soluble chitosan ( $\mathrm{g}$ ) and $\Delta \mathrm{W}_{\text {inh }}$ is weight differences of tinplate with the addition of water-soluble chitosan $(\mathrm{g})$.

\section{WSC inhibition analysis based on potentiodynamic polarization method}

Potentiodynamic polarization method was performed by Metrohm Autolab (PGSTAT302N) and processed by Nova 1.11 software. Potentiodynamic polarization method was performed by 3 electrodes cell with tinplate as working electrode, platinum wire as auxiliary electrode and $\mathrm{Ag} / \mathrm{AgCl}(\mathrm{KCl} 3 \mathrm{M})$ as reference electrode. This method was scanned at potential range of -150 to $+150 \mathrm{mV}$ and the scanning rate at $1 \mathrm{mV} / \mathrm{s}$. Tinplate surface $(4 \mathrm{~cm} \times 1 \mathrm{~cm} \times 0.1 \mathrm{~cm})$ was washed with water and acetone. Tinplate was coated with commercial waterproof coating paint. The corrosion media was prepared using $2 \%$ $\mathrm{NaCl}$ with and without the addition of WSC from shrimp shells at various concentrations $(0,10,250,200,750,1000,1300$ and 1500 $\mathrm{mg} / \mathrm{L}$ ). Tinplate, auxiliary and reference electrodes were soaked in 25 $\mathrm{mL}$ of corrosion media for 20 minutes and then tested by potentiostat instrument. The data from this method was curve between potential and current density log function which called as Tafel plot. The Tafel plot was extrapolated. The Tafel plot would delivere some data such as corrosion potential $\left(\mathrm{E}_{\mathrm{corr}}\right)$, corrosion current density ( $\left.\mathrm{I}_{\text {corr }}\right)$, cathodic Tafel slope $\left(\beta_{\mathrm{c}}\right)$, and anodic Tafel slope $\left(\beta_{\mathrm{a}}\right)$. The corrosion rates $(\mathrm{CR})$ and inhibition efficiencies (EI) were calculated using Eq. (5) and (6), respectively.

$$
\begin{gathered}
C R(\text { mmpy })=\frac{0.00327 \times I_{\text {corr }}(E W)}{\rho} \\
I E(\%)=\frac{I_{\text {corr blank }}-I_{\text {corr inh }}}{I_{\text {corr blank }}} \times 100
\end{gathered}
$$

$\mathrm{I}_{\text {corr }}$ is the current density of tinplate, $\rho$ is density of tinplate $\left(\mathrm{g} / \mathrm{cm}^{3}\right)$, $\mathrm{EW}$ is equivalent weight of tinplate $(\mathrm{g} / \mathrm{mol}), \mathrm{I}_{\text {corr blank }}$ is current density of tinplate without the addition of water-soluble chitosan and $\mathrm{I}_{\text {corr inh }}$ is current density of tinplate with the addition of water-soluble chitosan. The schematic diagram for preparation of water-soluble chitosan as corrosion inhibitor on tinplate in $\mathrm{NaCl} 2 \%$ was shown in Figure1.

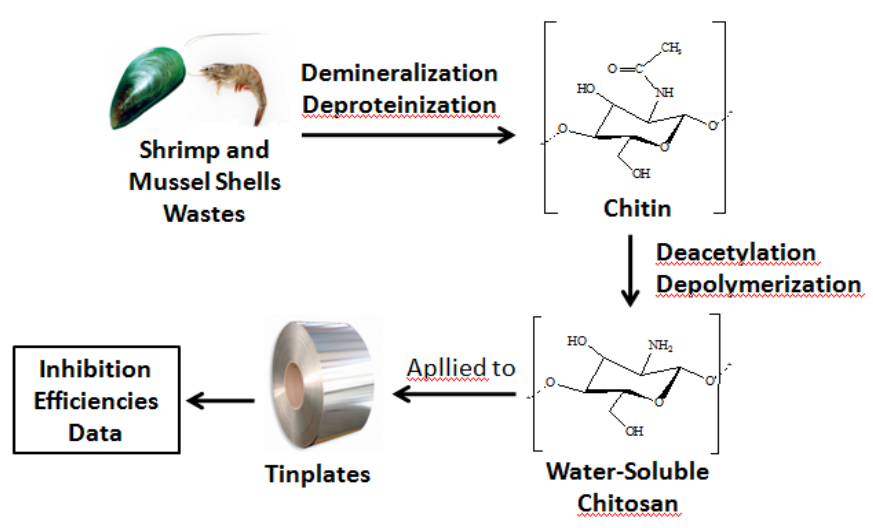

Figure 1. Schematic diagram for preparation of water-soluble chitosan as corrosion inhibitor on tinplate in $\mathrm{NaCl} 2 \%$. 


\section{RESULTS AND DISCUSSION}

\section{Percentages of chitin and water-soluble chitosan}

Water-soluble chitosan has been succesfully syntesized in this research. WSC was used as corrosion inhibitor on tinplate in $\mathrm{NaCl}$ $2 \%$. WSC was syntesized according to the research by Du et al. (2009). Shrimp and mussel shells powders were extracted from chitin by demineralization and deproteinization reactions. The demineralization process was carried out using $\mathrm{HCl} 7 \%$. Deproteinization process was carried out using $\mathrm{NaOH} 10 \%$. Chitin was deacetylated into crude chitosan using $\mathrm{NaOH} \mathrm{50 \% .} \mathrm{WSC} \mathrm{was}$ obtained by depolymerization of crude chitosan polymer chain using $\mathrm{CH}_{3} \mathrm{COOH} 2 \%$ and $\mathrm{H}_{2} \mathrm{O}_{2} 30 \%$. WSC from shrimp and mussel shells was hygroscopic white solid powder. WSC synthesis reaction from shrimp and mussel shells powders was shown in Figure 2.

Chitosan was insoluble in water and has poor solubility in neutral media which could limit its utilization (Du et al., 2009). Therefore, to increase the chitosan utilization, chitosan was needed to be converted to water-soluble chitosan with lower molecular weights. Chitosan solubility was related to its deacetylation degree (DD). DD (\%) of WSC in this research was $58.20 \%$. DD of WSC was obtained by acidbase titration method using $0.1045 \mathrm{~N} \mathrm{HCl}$. It showed that $58.20 \%$ of amide groups has become primary amine groups. Chitin and WSC percentages were shown in Table 1. WSC percentages of shrimp shells have higher value than from mussel shells. The lower percentages of chitin content from mussel shells compared to shrimp shells waste might be related to the composition of their shell. Further study about the composition of mussel shells and shrimp shells might be required.

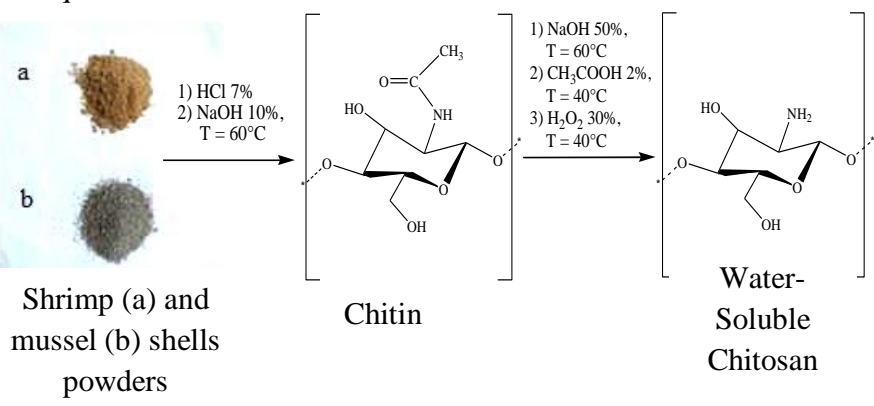

rigure 2 vVSC synthesis reaction (Du et al., 2009).

Table 1 Average percentage of chitin and WSC from shrimp and mussel shells wastes.

\begin{tabular}{lcc}
\hline & Shrimp shells & Mussel shells \\
\hline Chitin (\%) & 39.04 & 18.68 \\
WSC (\%) & 27.03 & 3.24 \\
\hline
\end{tabular}

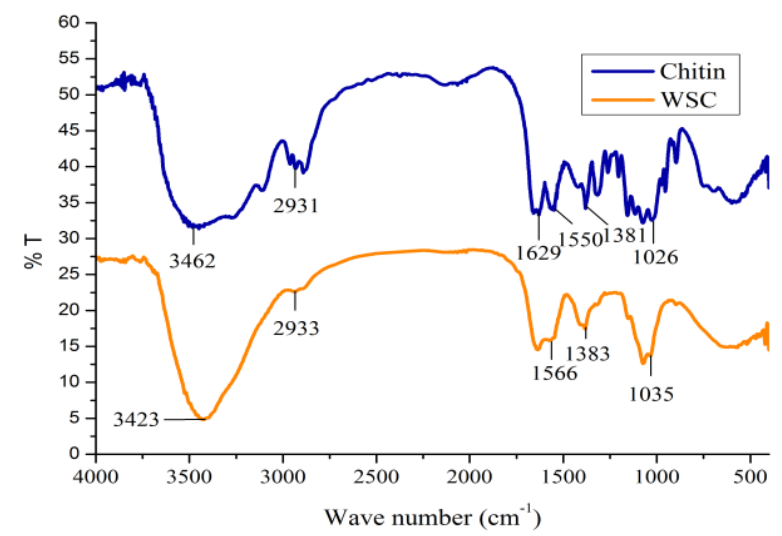

Figure 3 Chitin and WSC FTIR spectra derived from shrimp shells.

The FTIR spectra of chitin and WSC from shrimp shells were shown in Figure 3. Both FTIR spectra of chitin and chitosan have identical characteristics with that from literature (Kumari et al., 2015).
In FTIR spectra of chitin, there were peaks at $3462.34 \mathrm{~cm}^{-1}(\mathrm{O}-\mathrm{H}$ streching vibration), $2931.90 \mathrm{~cm}^{-1}\left(\mathrm{C}-\mathrm{H} \mathrm{sp}{ }^{3}\right.$ vibration), $1629.90 \mathrm{~cm}^{-1}$ $\left(\mathrm{C}=\mathrm{O}\right.$ amide streching vibration), $1550.82 \mathrm{~cm}^{-1}$ ( $-\mathrm{NH}$ amide bending vibration), $1381.08 \mathrm{~cm}^{-1}$ (C-N amide streching vibration) and 1026.16 $\mathrm{cm}^{-1}$ ( $-\mathrm{C}-\mathrm{O}-\mathrm{C}$ streching vibration). In FTIR spectra of WSC, there were peaks at $3423.76 \mathrm{~cm}^{-1}$ (O-H streching vibration), $2933.83 \mathrm{~cm}^{-1}$ (C-H vibration), $1566.25 \mathrm{~cm}^{-1}\left(\mathrm{~N}-\mathrm{H}_{2}\right.$ bending vibration), $1383.01 \mathrm{~cm}^{-1}$ $\left(\mathrm{C}-\mathrm{NH}_{2}\right.$ streching vibration) and $1031.95 \mathrm{~cm}^{-1}(-\mathrm{C}-\mathrm{O}-\mathrm{C}$ streching vibration).

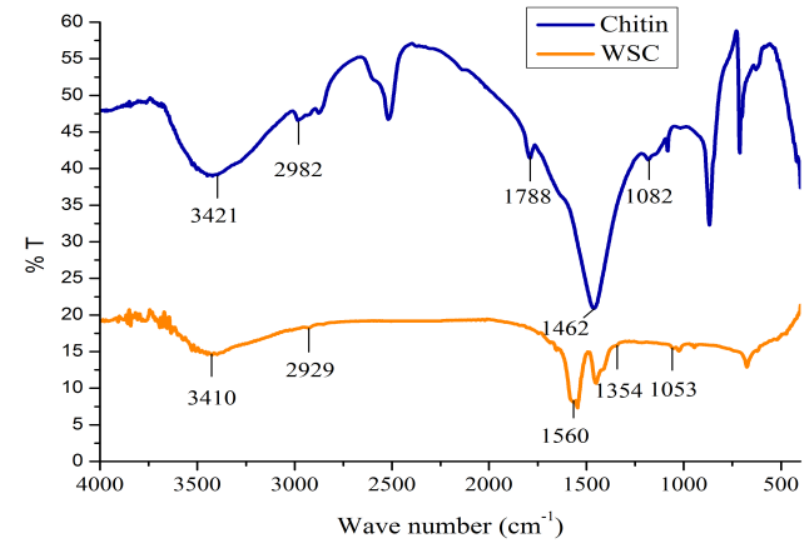

Figure $\mathbf{4}$ Chitin and WSC FTIR spectra derived from mussel shells.

The FTIR spectra of chitin and WSC from mussel shells were shown in Figure 4. Both FTIR spectra of chitin and chitosan have identical characteristics with that from literature (Ramasamy et al., 2014). In FTIR spectra of chitin, there were peaks at $3421.83 \mathrm{~cm}^{-1}$ (O-H streching vibration), $2982.05 \mathrm{~cm}^{-1}$ (C- $\mathrm{H} \mathrm{sp}^{3}$ vibration), 1788.07 $\mathrm{cm}^{-1}\left(\mathrm{C}=\mathrm{O}\right.$ amide streching vibration), $1462.09 \mathrm{~cm}^{-1}$ (-NH amide bending vibration) dan $1082.10 \mathrm{~cm}^{-1}(-\mathrm{C}-\mathrm{O}-\mathrm{C}$ streching vibration). In FTIR spectra of WSC, there were peaks at $3410.26 \mathrm{~cm}^{-1}$ (streching vibration $\mathrm{O}-\mathrm{H}), 2929.97 \mathrm{~cm}^{-1}\left(\mathrm{C}-\mathrm{H}\right.$ vibration), $1560.46 \mathrm{~cm}^{-1}\left(\mathrm{~N}-\mathrm{H}_{2}\right.$ bending vibration), $1354.07 \mathrm{~cm}^{-1}\left(\mathrm{C}-\mathrm{NH}_{2}\right.$ streching vibration) and $1053.17 \mathrm{~cm}^{-1}$ (-C-O-C streching vibration). Based on FTIR spectra in Figure 3 and 4, WSC were succesfully syntesized from shrimp and mussel shells wastes. The FTIR spectra of chitosan and WSC were not significantly different. The functional groups of chitosan and WSC were similar but, the polymer chain length was different. The difference in the chain length would possibly influence solubility in water. Further study on chitosan and WSC solubility could be investigated in the next research.

\section{Inhibition efficiencies of water-soluble chitosan based on weight loss method}

Inhibition analysis by weight loss method was used to obtain corrosion rates $(\mathrm{CR})$, surface coverages $(\theta)$ and inhibition efficiencies (IE) of WSC from shrimp and mussel shells wastes at various concentrations $(10-1500 \mathrm{mg} / \mathrm{L})$ in $2 \% \mathrm{NaCl}$. The average corrosion parameters of WSC from shrimp and mussel shells wastes were shown in Table 2 and 3, respectively. The curves of WSC concentrations derived from shrimp and mussel shells against inhibition efficiencies by weight loss method were shown in Figure 5.

Based on Figure 5 and corrosions parameters in Table 2 and 3, the inhibition efficiencies of WSC from shrimp and mussel shells by weight loss method have identical characteristics but have different values. The maximum inhibition efficiencies of WSC from shrimp and mussel shells were $72.73 \%$ and $54.55 \%$, respectively, by the addition of $1300 \mathrm{mg} / \mathrm{L}$ WSC. Inhibition efficiency was increased as the WSC concentration was increased.The maximum inhibition efficiency was achieved by the addition of $1300 \mathrm{mg} / \mathrm{L}$ WSC. The presence of WSC (10-1300 mg/L) could block the corrosion sites, so metal dissolvation process could be inhibited (Bhawsar et al., 2015). WSC at higher concentration, $>1300 \mathrm{mg} / \mathrm{L}$, was not adsorbed well to the metal surface, resulting in the increase of its diffusion to the solution and the decrease in the inhibition efficiency. Chitosan from mussel shells has a high mineral content even after demineralization 
process. High mineral content in chitosan could form complex bonds with amino groups in chitosan molecule, inducing the chitosan obtained to be in a little amount and became less efficient to inhibit the corrosion (Pursetyo et al., 2017).

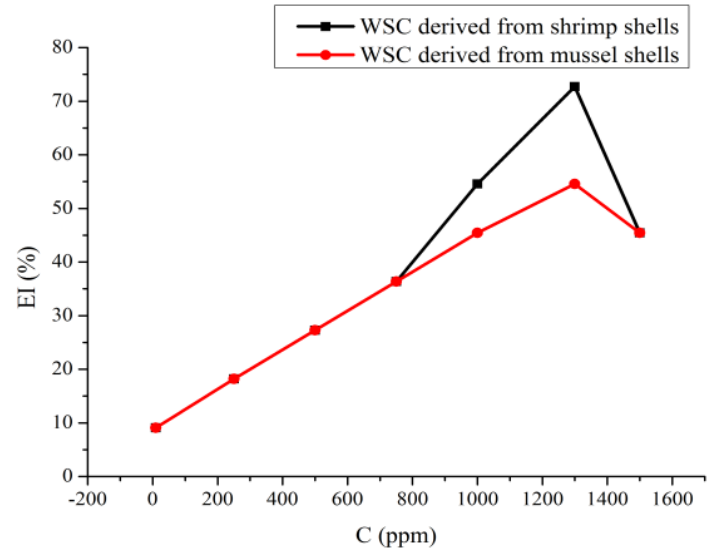

Figure 5 The curves of WSC concentration derived from shrimp and mussel shells against inhibition efficiency by weight loss method.

Table 2 Average corrosion parameters and inhibition efficiencies (IE) of shrimp shells WSC on tinplate in $2 \% \mathrm{NaCl}$ by weight loss method.

\begin{tabular}{ccccc}
\hline $\begin{array}{c}\text { WSC } \\
\text { conc.(mg/L) }\end{array}$ & $\begin{array}{c}\text { (W-W') } \\
(\mathbf{g})\end{array}$ & $\begin{array}{c}\text { CR } \\
\left(\mathbf{1 0}^{-\mathbf{1 0}} \mathbf{~ m m p y )}\right.\end{array}$ & $\boldsymbol{\theta}$ & IE (\%) \\
\hline 0 & 0.0011 & 2.09 & & \\
10 & 0.0010 & 1.90 & 0.09 & 9.09 \\
250 & 0.0009 & 1.71 & 0.18 & 18.18 \\
500 & 0.0008 & 1.52 & 0.27 & 27.27 \\
750 & 0.0007 & 1.33 & 0.36 & 36.36 \\
1000 & 0.0005 & 0.95 & 0.55 & 54.55 \\
1300 & 0.0003 & 0.57 & 0.73 & 72.73 \\
1500 & 0.0006 & 1.14 & 0.45 & 45.45 \\
\hline
\end{tabular}

Table 3 Average corrosion parmeters and inhibition efficiencies (IE) of mussel shells WSC on tinplate in $2 \% \mathrm{NaCl}$ by weight loss method.

\begin{tabular}{ccccc}
\hline $\begin{array}{c}\text { WSC conc. } \\
(\mathbf{m g} / \mathbf{L})\end{array}$ & $\begin{array}{c}\text { (W-W') } \\
(\mathbf{g})\end{array}$ & $\begin{array}{c}\mathbf{C R} \\
\left(\mathbf{1 0}^{-\mathbf{1 0}} \mathbf{~ m m p y}\right)\end{array}$ & $\boldsymbol{\theta}$ & IE $(\%)$ \\
\hline 0 & 0.0011 & 2.09 & & \\
10 & 0.0010 & 1.90 & 0.09 & 9.09 \\
250 & 0.0009 & 1.71 & 0.18 & 18.18 \\
500 & 0.0008 & 1.52 & 0.27 & 27.27 \\
750 & 0.0007 & 1.33 & 0.36 & 36.36 \\
1000 & 0.0006 & 1.14 & 0.45 & 45.45 \\
1300 & 0.0005 & 0.95 & 0.55 & 54.55 \\
1500 & 0.0006 & 1.14 & 0.45 & 45.45 \\
\hline
\end{tabular}

\section{Inhibition efficiencies of water-soluble chitosan based on potentiodynamic polarization method}

Corrosion inhibition analysis by potentiodynamic polarization method was used to obtain inhibition efficiencies (IE) and inhibiton type from shrimp shells waste WSC at various concentrations (10$1500 \mathrm{mg} / \mathrm{L}$ ) in $2 \% \mathrm{NaCl}$. Furthermore, WSC inhibition analysis was used to support the data from weight loss method. Tafel plots from potentiodynamic polarization analysis were shown in Figure 6. Tafel plots were extrapolated to obtain corrosion parameters such as $\mathrm{I}_{\text {cor }}$ and $\mathrm{E}_{\text {corr. }}$ and shown in Table 4 . The curves of WSC concentration derived from shrimp shells against inhibition efficiency by weight loss and potentiodynamic polarization methods were shown in Figure 6. Based on Figure 7, it was found that the curves between WSC concentration of shrimp shells and its IE which obtained by weight loss and potentiodynamic polarization method have identical characteristics.

The addition of 10-1300 mg/L WSC could decrease $\mathrm{I}_{\text {corr. }}$ It was caused by the adsorption of WSC molecules on tinplate surface and thus, forms protective layer. So it could decrease the corrosion rates
(Pursetyo et al., 2017). Maximum inhibition efficiency of shrimp WSC by potentiodynamic method was $91.41 \%$ by the addition of $1300 \mathrm{mg} / \mathrm{L}$ WSC. The addition of $1500 \mathrm{mg} / \mathrm{L}$ WSC, resulted in the increase of $\mathrm{I}_{\text {corr }}$. It was possibly caused by the desorption of protective layer into solution. Based on Table 4, the differences between $E_{\text {corr }}$ of blank solution and $\mathrm{E}_{\text {corr }}$ of $\mathrm{NaCl} 2 \%$ by the addition of WSC were less than $85 \mathrm{mV}$. It could be concluded that WSC was a mixed type of inhibitor (anodic and chatodic) (Anshari \& Quraishi, 2014). Anodic reaction was related to metal dissolution process, while chatodic reaction was related to $\mathrm{H}_{2}$ formation.

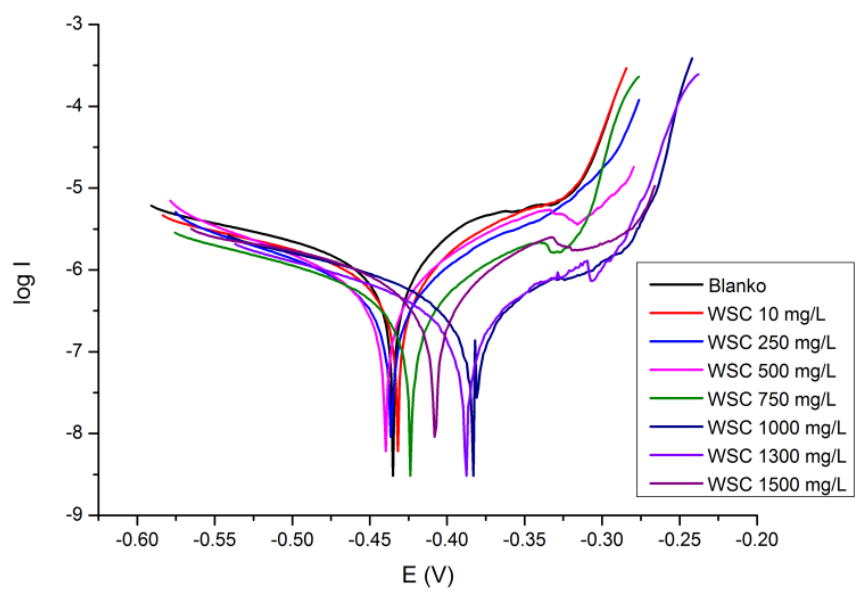

Figure 6 Tafel plots of tinplate in $\mathrm{NaCl} 2 \%$ by the addition of shrimp shells WSC.

Table 4 Average corrosion parameters and inhibition efficiencies (IE) of shrimp shells WSC on tinplate in $\mathrm{NaCl} 2 \%$ by potentiodynamic method.

\begin{tabular}{rccrccc}
\hline $\begin{array}{c}\text { WSC } \\
\text { conc. } \\
(\mathbf{m g} / \mathbf{L})\end{array}$ & $\begin{array}{l}\text { E } \\
(\mathbf{m} \text { corr })\end{array}$ & $\boldsymbol{\beta}_{\mathbf{a}}$ & $\boldsymbol{\beta}_{\mathbf{c}}$ & $\begin{array}{c}\mathbf{I}_{\mathbf{c o r r}}(\boldsymbol{\mu A} \\
\left./ \mathbf{c m}^{2}\right)\end{array}$ & $\begin{array}{c}\mathbf{C R} \\
(\mathbf{m m p y}\end{array}$ & $\begin{array}{c}\text { IE } \\
(\boldsymbol{\%})\end{array}$ \\
\hline 0 & -434.23 & 389.59 & 99.07 & 1.74975 & 0.047 & \\
10 & -432.81 & 179.39 & 82.66 & 0.92066 & 0.025 & 47.38 \\
250 & -437.11 & 250.53 & 116.66 & 0.85460 & 0.022 & 51.16 \\
500 & -435.47 & 160.94 & 177.34 & 0.77062 & 0.021 & 55.96 \\
750 & -415.56 & 274.61 & 122.25 & 0.61461 & 0.016 & 64.87 \\
1000 & -389.99 & 109.85 & 74.98 & 0.31932 & 0.009 & 81.75 \\
1300 & -387.74 & 79.42 & 53.29 & 0.15030 & 0.004 & 91.41 \\
1500 & -421.53 & 193.87 & 141.73 & 0.65521 & 0.018 & 62.55 \\
\hline
\end{tabular}

It was found that the inhibition efficiencies of WSC from shrimp shells tested by weight loss and potentiodynamic polarization methods have identical characteristics although at different values, as indicated from Figure 7 and Table 2 and 4.

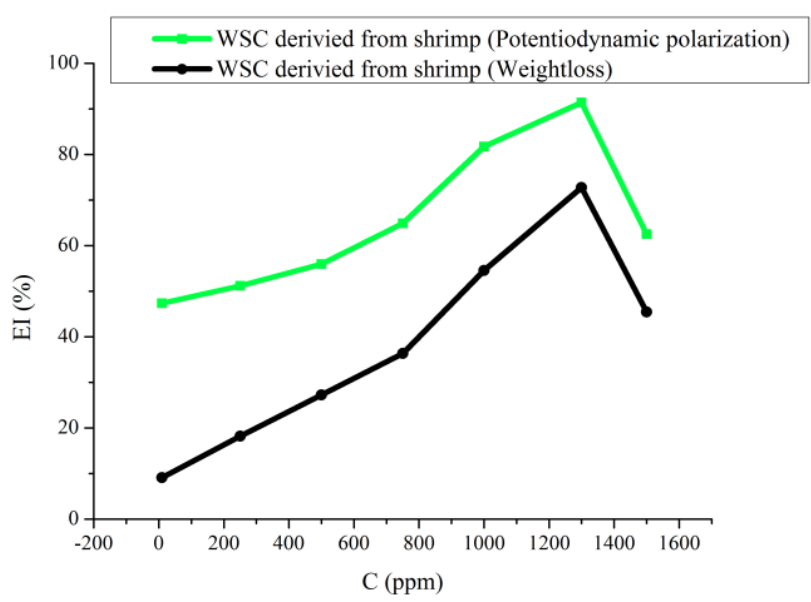

Figure 7 The curves of WSC concentration derived from shrimp shells against inhibition efficiency by weight loss and potentiodynamic polarization methods. 
The maximum inhibition efficiency of WSC from shrimp shells by weight loss method was $72.73 \%$ and the maximum inhibition efficiency of WSC from shrimp shells by potentiodynamic polarization method was $91.41 \%$ by the addition of $1300 \mathrm{mg} / \mathrm{L}$ WSC. Inhibition efficiency was increased as WSC concentration was increased, with maximum inhibition efficiency at the addition of $1300 \mathrm{mg} / \mathrm{L}$ WSC.

Adsorption isotherm and corrosion thermodynamic studies

The corrosion inhibition mechanism could be studied by adsorption isotherm models of WSC on tinplate surface. There were a lot of adsorption isotherm models, such as Langmuir, Freundlich, Temkin, Frumkin and Flory-Huggins. Adsorption isoterm of WSC was obtained by ploting linear curve based on some equations of adsorption isotherm mentioned above (Sangeetha et al., 2016). Adsorption isotherm curve of shrimp shells WSC was shown in Figure 8 (a) and adsorption isotherm curve of mussel shells WSC was shown in Figure 8 (b).
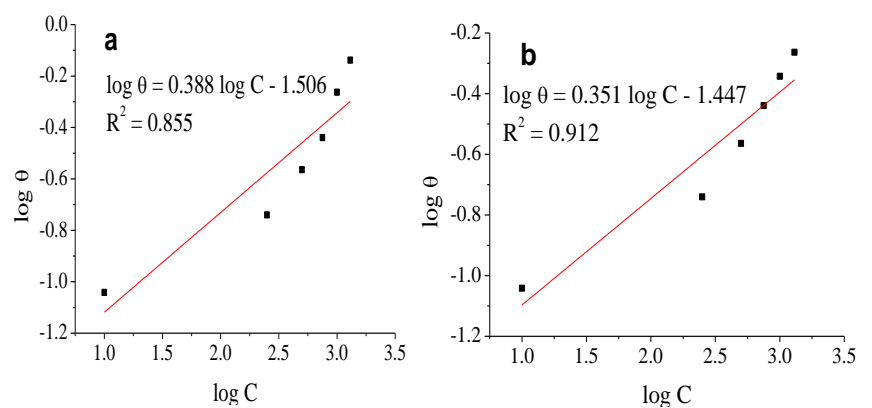

Figure 8 Freundlich adsorption isotherm of WSC from shrimp (a) and mussel (b) shells wastes.

WSC adsorption isotherm was obeyed Freundlich isotherm with correlation coefficients of 0.855 (WSC from shrimp shells) and 0.912 (WSC from mussel shells). The correlation coefficients of WSC from shrimp and mussel shells wastes were not linear, the tin plating $(\mathrm{Sn})$ on both sides of tinplate was performed by hot dipping. Based on the Sn coating study, it was possible that the Sn layer formed has ununiform thickness. The FeSn 2 layer formed on the tinplate surface was served as protective layer that preventing steel corrosion (Martins, 2012). Different Sn coating thicknesses could cause WSC molecule adsorption on tinplate surface to be not uniform, making-the regressions of WSC Freundlich adsorption isotherm from shrimp and mussel shells wastes were not linear.

Freundlich adsorption isotherm indicated that the interaction was not only between WSC molecule and tinplate, but also from interaction between WSC molecule and its solution, resulting in the decrease in the value of WSC inhibition efficiency on tinplate after the addition of maximum concentration. Based on Freundlich equation (Figure 8), the $\mathrm{k}_{\text {ads }}$ values (adsorption-desorption constant) of WSC were calculated from equation 7.

$$
\log \theta=\log K_{a d s}+n \log C
$$

The $k_{\text {ads }}$ values (adsorption-desorption constant) of WSC from shrimp and mussel shells wastes were 0.0312 and 0.0357 , respectively. The $\Delta \mathrm{G}^{\circ}$ ads (free Gibbs adsorption energy) values were calculated from equation 8 .

$$
k_{a d s}=\frac{1}{1000} \exp \left[\frac{-\Delta G_{a d s}^{o}}{R T}\right]
$$

The $\Delta \mathrm{G}_{\text {ads }}^{\circ}$ values (free Gibbs adsorption energy) were -8.523 $\mathrm{kJ} / \mathrm{mol}$ and $-8.858 \mathrm{~kJ} / \mathrm{mol}$ respectively. Negative value of $\Delta \mathrm{G}^{\circ}$ ads showed that inhibitor adsorption process was spontaneous (Yaro et al., 2013). $\Delta \mathrm{G}^{\circ}$ adsvalues that higher than $-20 \mathrm{~kJ} / \mathrm{mol}$ indicated that the adsorption of WSC molecules on tinplate surface was physisorption.

\section{CONCLUSION}

Water-Soluble Chitosan (WSC) from shrimp and mussel shells wastes were good candidates for green corrosion inhibitors that acted efficiently on tinplate in $\mathrm{NaCl} 2 \%$. Maximum inhibition efficiencies by weight loss method of WSC derived from shrimp shells and mussel shells wastes were $72.73 \%$ and $54.55 \%$, respectively. The the maximum inhibition efficiency was obtained by the addition of 1300 $\mathrm{mg} / \mathrm{L}$ WSC. Weight loss studies revealed that WSC was acted as a mixed type of inhibitor and obeyed Freundlich adsorption isotherm. Inhibition efficiency of WSC derived from shrimp shells was higher than WSC derived from mussel shells. So, the inhibition efficiency of shrimp shells WSC by weight loss method was confirmed by potentiodynamic polarization method which was $91.41 \%$.

\section{ACKNOWLEDGEMENT}

The financial supports from the Institute for research and community services (LPPM, Lembaga Penelitian dan Pengabdian Masyarakat) ITS (726/PKS/ITS/2017), and the facilities supports from Chemistry Department, Faculty of Mathematic and Natural Sciences, Institut Teknologi Sepuluh Nopember Surabaya (ITS) were acknowledged.

\section{REFERENCES}

Aghzzaf, A.A., Rhouta, B., Steinmetz, J., Rocca, E., Aranda, L., Khalil, A., Yvon, J., Daoudi, L. 2012. Corrosion inhibitors based on chitosanheptanoate modified beidellite. Applied Clay Science, 65-66, 173-178.

Anejjar, A., Salghi, R., Zarrouk, A., Benali, O., Zarrok, H., hammouti, B., Ebenso, E.E. 2014. Inhibition of carbon steel corrosion in $1 \mathrm{M} \mathrm{HCl}$ medium by potassium thiocyanate. Journal of the Association of Arab Universities for Basic and Applied Sciences, 15, 22-27.

Anshari, K.R., Quraishi, M.A. 2014. effect of three component (anilineformaldehyde and piperazine) polymer on mild steel corrosion in hydrochloric acid medium. Journal of the Association of Arab Universities for Basic and Applied Sciences, 18, 12-18.

Arancibia, M.Y., Aleman, A., Calvo, M.M., Lopez-Caballero, M.E., Montero, P., Gomez-Guillen, M.C. 2014. antimicrobial and antioxidant chitosan solutions enriched with active shrimp (Litopenaeus vannamei) waste materials. Food Hydrocolloids, 35, 710-717.

Balaji, J., Sethuraman, M.G. 2017. Chitosan-doped-hybrid/TiO nanocomposite based sol-gel coating for the corrosion resistance of aluminum metal in 3,5\% $\mathrm{NaCl}$ medium. International Journal of Biological Macromolecules, 104.

Bhawsar, J., Jain, P.K., Jain, P. 2015. experimental and computational studies of Nicotiana tabacum leaves extract as green corrosion inhibitor for mild steel in acidic medium. Alexandria Engineering Journal, 54, 769-775.

Catala, R., Cabanes, J.M., Bastidas, J.M. 1998. An impedance study on the corrosion properties of lacquered tinplate cans in contact with tuna and mussels in pickled sauce. Corrosion Science, 40, 1455-1467.

Czechowska-Biskup, R., Jarosińska, D., Rokita, B., Ulański, P., Rosiak, J.M. 2012. Determination of degree of deacetylation of chitosan- Comparison of methods. Progress on Chemistry and Application of Chitin and its Derivatives, 18, 5-20.

Du, Y., Zhao, Y., Dai, S., Yang, B. 2009. Preparation of water-soluble chitosan from shrimp shell and its antibacterial activity. Innovative Food Science and Emerging Technologies, 10, 103-107.

El-Haddad, M. 2013. Chitosan as a green inhibitor for copper corrosion in acidic medium. International Journal of Biological Macromolecules, 55, 142-149.

Firdausi, S., Harmami 2014. Optimasi waktu dan potensial dalam pelapisan kitosan pada tin plate secara elektroforesis. Jurnal Sains dan Seni ITS, 1 No. 1, 1-5.

Ghorbel-Bellaaj, O., Hajji, S., Younes, I., Chaabouni, M., Nasri, M., Jellouli, K.. 2013. Optimization of chitin extraction fron shrimp waste with Bacillus pumilus A1 using response surface methodology. International Journal of Biological Macromolecules, 61, 243-250.

Hamdani, N.E., Fdil, R., Tourabi, M., Jama, C., Bantiss, F. 2015. Alkaloids Extract of Retama monosperma (L.) Boiss. Seeds used as novel ecofriendly inhibitor for carbon steel corrosion in $1 \mathrm{M} \mathrm{HCl}$ solution: Electrochemical and surface studies. Applied Surface Science, 357, 1294-1305.

Huang, X., Lang, F., Ma, Y., Chen, Y., Zhang, Z., Zhang, J. 2014. Effects of reflowing temperature and time on alloy layer of tinplate and its electrochemical behavior in $3.5 \% \mathrm{NaCl}$ solution. Transactions of Nonferrous Metals Society of China, 24, 1978-1988. 
Kumari, S., Rath, P., Kumar, A.S.H., Tiwari, T.N. 2015. Extraction and caracterization of chitin and chitosan from fishery waste by chemica method. Environmental Technology \& Innovation, 3, 77-85.

Pursetyo, K.T., Purbowati, P., Sulmartiwi, L. 2017. Degree of deacetylation chitosan from pen shell (Atrina pectinata) with multistage deacetylation process. AIP Conference Proceedings, 1813 (1), 020019.

Ramasamy, P., Subhapradha, N., Shanmugam, V., Shanmugam, A. 2014. Extraction, characterization and antioxidant property of chitosan from cuttlebone Sepia kobiensis (Hoyle 1885). International Journal of Biological Macromolecules, 64, 202-212.

Riszki, T.I., Harmami 2015. Pengaruh suhu terhadap kualitas coating (pelapisan) stainless steel Tipe 304 dengan kitosan secara elektroforesis. Jurnal Sains dan Seni ITS, 4 No. 1, 2337-3250.

Ruhi, G., Modi, O.P., Dhawan, S.K. 2015. Chitosan-polypyrrole-SiO composite coatings with advanced anticorrosive properties. Synthetic Metals, 200, 24-39.

Saleh, C.W., Harmami, Ulfin, I. 2017. pengendalian korosi menggunakan inhibitor kitosan larut air untuk baja lunak dalam media $\mathrm{HCl} 1 \mathrm{M}$. Jurnal Sains dan Seni ITS, 6 No. 1, 2337-3250.
Sangeetha, Y., Meenakshi, S., Sundaram, C. S. 2016. Interactions at the mild steel acid solution interface in the presence of O-fumaryl-chitosan: Electrochemical and surface studies. Carbohydrate Polymers, 136, 38-45.

Trethewey, K.R and Chamberlain, J. 1991. Korosi untuk mahasiswa dan rekayasawan. PT Gramedia Pustaka Utama : Jakarta.

Verma, C., Ebenso, E.E., Quraishi, M.A. 2017. ionic liquids as green and sustainable corrosion inhibitors for metals and alloys : An overview. Journal of Molecular Liquids, 233, 403-414.

Wardani, L.A., Harmami. 2014. Optimasi pelapisan SS 304 dengan kitosan secara elektroforesis. Jurnal Sains dan Seni ITS, 1 No. 1, 1-4.

Xia, D., Song, S., Wang, J., Bi, H., Jiang, Y., Han, Z. 2012. Corrosion behavior of tinplate in $\mathrm{NaCl}$ Solution. Transactions of Nonferrous Metals Society of China, 22, 717-724.

Yaro, A.S., Khadom, A.A., Wael, R.K. 2013. Apricot juice as green corrosion inhibitor of mild steeel in phosphoric acid. Alexandria Engineering Journal, 52, 129-135. 